\title{
Appendix A: Project Characteristics
}

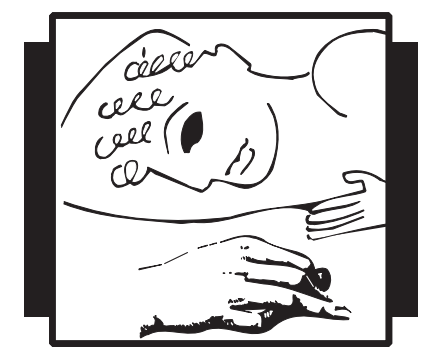

\section{Tool Sheet: The Project Portrait}

\section{What}

The project portrait is a starting point for identification and analysis of the characteristics and challenges of a project, a basis for understanding the specific conditions for approach and management, and a basis for identification of points of attention.

Large projects involve many persons - either directly in the project work or indirectly as future users of the project product. A common understanding of the project is needed - not just the expected result, but also the nature of the project and its critical elements and conditions (points of special attention). The portrait may be a means of creating a common understanding.

The project portrait illustrates the character and importance of the points of attention and is the basis for a focused management effort.

\section{Use - Where and When}

The portrait is usually drawn already at the project beginning and contributes to defining scope, approach, and organization. It is normally revised at the beginning of new phases. 


\section{Method}

\section{Four Pictures of the Project}

The portrait consists of four perspectives, each shedding light on central aspects of the project, and leading to four pictures:

- The entrepreneurial picture - Illustrating the degree of clearness of benefits, of goals, of costs, and of opportunities for business success.

- The technical picture - Illustrating the clearness of the technical area of the project result (solution) and of the effect of technical approach and methods.

- The organizational picture - Illustrating the degree of understanding of the project importance and consequences in the organization and the will to complete the project.

- The political picture - Illustrating the conflicting interests around the project.

Each picture is structured according to the five elements of the five-by-five model - see Figure A1. The degree of difficulty (uncertainty, opaqueness, etc.) is described on a scale from 0 to 5. The actual project is analyzed and evaluated according to the scale, and a score is assigned. The idea is to direct project management effort to the most challenging elements in the project.

\section{The Portrait}

In Figure A2 the four scores for the actual project from Figure A1 may be plotted on the frame forming a rectangle. Figure A3 shows five examples of portraits indicating that projects call for different kinds of attention.

Some projects have most of the weight in one axis, but usually the project picture will include all four axes. The points on the axes indicate the degree of difficulty. A small shaded area represents an easy project and a large area represents a difficult project. 


\section{The technical aspect}

0

\section{The project task}

Benefit goals and product goals are defined and the elements of the project are known. Project scope and limits are defined.

\section{Environment}

Technical and systems environment for the project and its product is known and relatively stable.

\section{Interested parties}

There is a good harmony around technical aspects, and possible disagreements can be solved through analysis and debate.

\section{Resources}

Need of resources can be estimated and competencies are available.
Benefit goals are not operationally defined and product goals and possible solutions are unclear. New developments are required. It is a complicated task.

There are complicated and unclear interfaces and connections to external systems.

There are divergent technical points of view and opinions. They are strongly advocated, and conflict solving may be difficult.

Resource estimating and budgeting is difficult. Difficult to foresee the need for specialist competence.

Planning is challenging and uncertain. Short planning horizon.

\section{Course of action}

Project structure and approach are visible and a milestone plan can be prepared.

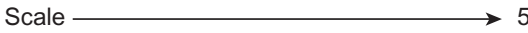

\section{Environment}

External conditions are relatively stable and foreseeable. Project priority versus competing projects is defined.

\section{Interested parties}

Project benefits are visible and there is a strong coalition of stakeholders.

\section{Resources}

Stakeholders will provide necessary resources, based on a realistic budget.

\section{Course of action}

Planning is possible and speed is expected.
Project benefits are not operationally defined. The strategic value and the level of ambition are not clear.

External turbulence may change the strategic importance and the benefits of the project. There are important competing projects.

Stakeholders have conflicting interests and the external turbulence may change their priorities.

Resources are scarce and will only be provided by negotiation and good arguments.

Maneuverability is necessary.

\section{Figure A1. Four Pictures.}




\section{The organizational aspect}

0

\section{Project task}

The project task and the solutions/products are understood by the users and other interested parties.

\section{Environment}

It is possible to explain connections between project products and their environment.

\section{Interested parties}

Users' understanding, knowledge and acceptance will be achieved through information and training.

\section{Resources}

The project can be managed as a 'pull' project. The user organization is committed and will provide resources.

\section{Course of action}

Anchoring will be achieved by involvement in the project work and by user training.
Scale

The degree of new development and complexity makes it difficult for the users and other interested parties to understand and evaluate consequences.

It is difficult to describe and understand how project results will influence the environment - and vice versa.

It is a comprehensive and challenging task to obtain understanding, knowledge and willpower from important stakeholders especially users.

To some extent the project must be managed as a 'push' project. The user organization must be encouraged to participate.

Step-wise approach, visualization, test and new versions will be necessary to ensure anchoring.

\section{The political aspect}

\section{0}

\section{Project task}

Project goals are reasonable coherent - or a few superior goals are dominant.

\section{Environment}

There are several considerations related to the environment - but they are managed through standards, regulations, and economy.

\section{Interested parties}

There is a strong coalition of stakeholders around the project. Potential conflicts will be solved by mutual agreement.

\section{Resources}

Stakeholders are willing to contribute resources - provided that the project will fulfill the goals.

\section{Course of action}

The project plan will be realistic - but must be based on influence from important stakeholders.

\section{Scale $\longrightarrow 5$}

There are several conflicting project goals difficult to prioritize.

There are several considerations related to the environment - not coherent and difficult to prioritize.

There are essential conflicting interests around the project related to its relevance, scope and level of ambition. There are several powerful stakeholders.

Stakeholders have divergent opinions on best use of resources. Opinion formers influence the motivation to participate.

Power struggle, negotiations, degree of loyalty will influence the process. 


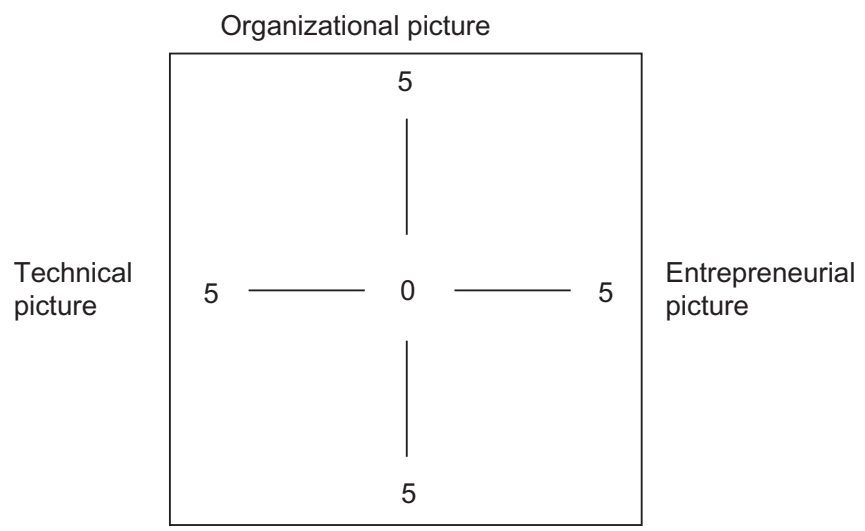

Political picture

Reasons for the picture:

(Special characteristics and challenges)

Figure A2. A Frame for the Portrait.

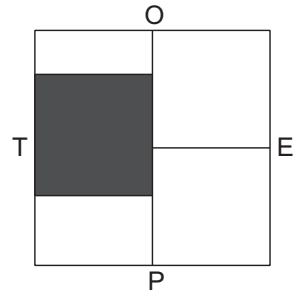

A technology development project

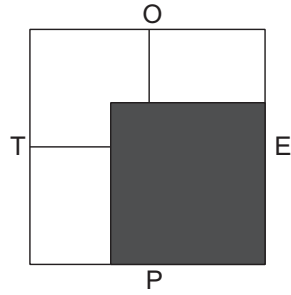

A product development project in the early stage

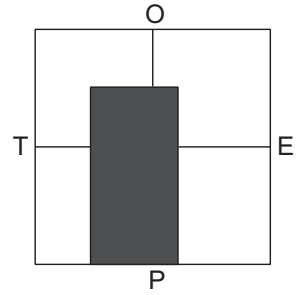

A systems development project with strong conflicts

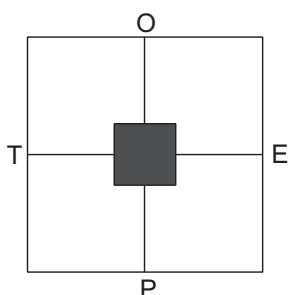

An implementation project

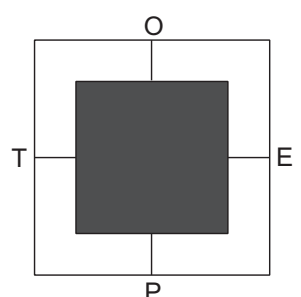

An organizational development project

Figure A3. Examples of Project Portraits. 


\section{Understanding and Insight}

The portrait may be created in two

Do not go on board on large projects with small ideas. ways - in a systematic-analytical way or in an intuitive-holistic way.

Figure A1 suggests a systematic way of creating a collective picture. Each participating person marks his evaluation of the five elements in each of the four pictures in the figure. The reasons for the evaluation should be noted, e.g., particular circumstances and characteristics. The participants compare their pictures and discuss differences. The discussion leads to a common picture and a list of challenges and points of special attention.

Figure A2 is used in the intuitive way. The participants draw a shaded rectangle directly - and explain the reasons. However, what you see depends on the seer, so the participants should discuss the pictures and draw a common picture.

\section{Points of Special Attention}

Each picture has a set of challenges and points of attention:

- The entrepreneurial picture: Attention to clarifying and elucidating the benefits and how the resource effort will lead to profit. Activities include visibility, internal marketing, lobbyism, enlisting sponsors/advocates, and on contribution agreements.

- The technical picture: Attention to unclear elements and uncertainties and challenges in the technical part of the project. Focus is on research, test, and specification.

- The organizational picture: Attention to understanding, competencies and confidence in the project and its scope. Focus on information, training, learning, and involvement.

- The political picture. Attention to powerful interested parties and their balancing of contribution and rewards. Focus on negotiation, adaptations, and persuasion. 
The challenges may point to certain approaches, countermeasures and management actions. The portrait clarifies requirements to management of a complex project.

\section{Connections Between the Pictures}

The four pictures are basically complementary, but their management requirements are linked. Understanding this creates synergy. For example:

- Focus on the project task may contribute to better conflict handling (the entrepreneurial picture and the political picture). Making the project visible to interested parties especially by emphasizing its benefits - enables each party to see its own contribution and benefit. It clarifies possible coalitions.

- A well-planned technical structure contributes to arranging a correspondingly clear project organization structure (the technical and the organizational picture). An unclear and complex technical structure, on the other hand, will lead to an effort for common clarification.

- A starting point in the entrepreneurial picture and the political picture with subsequent understanding of uncertainties, opaqueness, and counteractive elements may lead to better concept development (the technical picture).

\section{Extension of the Portrait}

The portrait may be supplemented by the tool 'Project challenges' - see tool sheet C.1. It presents more cues to identifying difficulties.

\section{Example}

Figure A3 shows examples of portraits. 


\section{Tool Sheet: Models of Project Management Functions}

Well-known models of the typical functions in project management exist - most of them developed by project management associations. For inspiration, we will show models from the Project Management Institute (PMI): Project management body of knowledge (PMBOK); The British Association for Project Management: APM BOK; The European association, IPMA: Competences in Project Management; and from PRINCE2.

\begin{tabular}{|c|c|c|}
\hline \multicolumn{3}{|c|}{ PMBOK Project Management } \\
\hline $\begin{array}{l}\text { Project Integration } \\
\text { Management }\end{array}$ & $\begin{array}{l}\text { Project Scope } \\
\text { Management }\end{array}$ & $\begin{array}{l}\text { Project Time } \\
\text { Management }\end{array}$ \\
\hline Project plan development & Initiation & Activity definition \\
\hline Project plan execution & Scope planning & Activity sequencing \\
\hline \multirow[t]{3}{*}{ Overall change control } & Scope definition & $\begin{array}{l}\text { Activity duration } \\
\text { estimating }\end{array}$ \\
\hline & Scope verification & Schedule development \\
\hline & Scope change control & Schedule control \\
\hline $\begin{array}{l}\text { Project Cost } \\
\text { Management }\end{array}$ & $\begin{array}{c}\text { Project Quality } \\
\text { Management }\end{array}$ & $\begin{array}{l}\text { Project Human } \\
\text { Resource } \\
\text { Management }\end{array}$ \\
\hline Resource management & Quality management & $\begin{array}{l}\text { Organizational } \\
\text { planning }\end{array}$ \\
\hline Cost estimating & Quality assurance & Staff acquisition \\
\hline Cost budgeting & Quality control & Team development \\
\hline Cost control & & \\
\hline
\end{tabular}




\section{PMBOK Project Management}

\begin{tabular}{lll}
$\begin{array}{l}\text { Project Communications } \\
\text { Management }\end{array}$ & $\begin{array}{c}\text { Project Risk } \\
\text { Management }\end{array}$ & \multicolumn{1}{c}{$\begin{array}{c}\text { Project Procurement } \\
\text { Management }\end{array}$} \\
\hline Communications planning & Risk identification & Procurement planning \\
Information distribution & Risk quantification & Solicitation planning \\
Performance reporting & $\begin{array}{l}\text { Risk response } \\
\text { development }\end{array}$ & Solicitation \\
& Risk response & Source selection \\
Administrative closure & control & \\
& & Contract administration \\
& & Contract close-out \\
\hline
\end{tabular}

APM BOK (UK) Project Management

\begin{tabular}{|c|c|c|}
\hline Planning the Strategy & Executing the Strategy & $\begin{array}{l}\text { Organization and } \\
\text { Governance }\end{array}$ \\
\hline $\begin{array}{l}\text { Project success criteria } \\
\text { and benefits management }\end{array}$ & Scope management & $\begin{array}{l}\text { Project life cycles } \\
\text { concept }\end{array}$ \\
\hline Stakeholder management & Scheduling & Definition \\
\hline Value management & Resource management & Implementation \\
\hline Risk management & $\begin{array}{l}\text { Budgeting and cost } \\
\text { management }\end{array}$ & $\begin{array}{l}\text { Hand-over and } \\
\text { close-out }\end{array}$ \\
\hline Quality management & Change control & Project reviews \\
\hline $\begin{array}{l}\text { Health, safety, and } \\
\text { environment }\end{array}$ & $\begin{array}{l}\text { Earned value } \\
\text { management }\end{array}$ & $\begin{array}{l}\text { Organization } \\
\text { structure }\end{array}$ \\
\hline \multirow[t]{3}{*}{$\begin{array}{l}\text { Project management } \\
\text { plan }\end{array}$} & $\begin{array}{l}\text { Information } \\
\text { management and } \\
\text { reporting }\end{array}$ & $\begin{array}{l}\text { Organizational } \\
\text { roles }\end{array}$ \\
\hline & Issue management & $\begin{array}{l}\text { Methods and } \\
\text { procedures }\end{array}$ \\
\hline & & Governance \\
\hline
\end{tabular}


APM BOK (UK) Project Management

\begin{tabular}{|c|c|c|}
\hline $\begin{array}{l}\text { Business and } \\
\text { Commercial }\end{array}$ & $\begin{array}{c}\text { People and the } \\
\text { Profession }\end{array}$ & Techniques \\
\hline Business case & Communication & $\begin{array}{l}\text { Requirements } \\
\text { management }\end{array}$ \\
\hline Marketing and sales & Teamwork & $\begin{array}{l}\text { Development } \\
\text { management }\end{array}$ \\
\hline Financial management & Leadership & Estimating \\
\hline Procurement & Conflict management & $\begin{array}{l}\text { Technology } \\
\text { management }\end{array}$ \\
\hline \multirow[t]{5}{*}{ Legal awareness } & Negotiation & Value engineering \\
\hline & $\begin{array}{l}\text { Human resource } \\
\text { management }\end{array}$ & Modeling and testing \\
\hline & Behavioral characteristics & $\begin{array}{l}\text { Configuration } \\
\text { management }\end{array}$ \\
\hline & $\begin{array}{l}\text { Learning and } \\
\text { development }\end{array}$ & \\
\hline & Professionalism and ethics & \\
\hline
\end{tabular}

IPMA Competence Baseline

\begin{tabular}{lll}
\hline $\begin{array}{l}\text { Plan and Evaluate the } \\
\text { Project Management }\end{array}$ & $\begin{array}{l}\text { Organize the Project } \\
\text { Management Phases }\end{array}$ & $\begin{array}{l}\text { Perform Overall Project } \\
\text { Management }\end{array}$ \\
\hline $\begin{array}{l}\text { Characterize project } \\
\text { and project } \\
\text { management }\end{array}$ & $\begin{array}{l}\text { Organize the project } \\
\text { preparation phase }\end{array}$ & $\begin{array}{l}\text { Analyze the project } \\
\text { process and } \\
\text { management }\end{array}$ \\
$\begin{array}{l}\text { Apply models for } \\
\text { project management }\end{array}$ & $\begin{array}{l}\text { Organize the project } \\
\text { start-up phase }\end{array}$ & $\begin{array}{l}\text { Handle anchoring with } \\
\text { the determining parties }\end{array}$ \\
$\begin{array}{l}\text { Plan the specific project } \\
\text { management effort }\end{array}$ & $\begin{array}{l}\text { Organize the } \\
\text { management of project } \\
\text { execution }\end{array}$ & $\begin{array}{l}\text { Develop the project } \\
\text { objectives }\end{array}$ \\
$\begin{array}{l}\text { Evaluate the performed } \\
\text { project management }\end{array}$ & $\begin{array}{l}\text { Organize the project } \\
\text { close-out phase }\end{array}$ & $\begin{array}{l}\text { Structure the project task } \\
\text { and clarify scope }\end{array}$
\end{tabular}


IPMA Competence Baseline

\begin{tabular}{|c|c|c|}
\hline $\begin{array}{l}\text { Plan and Evaluate the } \\
\text { Project Management }\end{array}$ & $\begin{array}{l}\text { Organize the Project } \\
\text { Management Phases }\end{array}$ & $\begin{array}{l}\text { Perform Overall Project } \\
\text { Management }\end{array}$ \\
\hline \multirow[t]{6}{*}{$\begin{array}{l}\text { Facilitate the project } \\
\text { management processes }\end{array}$} & & $\begin{array}{l}\text { Develop the approach } \\
\text { and master schedule }\end{array}$ \\
\hline & & $\begin{array}{l}\text { Design the project } \\
\text { organization structure }\end{array}$ \\
\hline & & $\begin{array}{l}\text { Provide staffing to the } \\
\text { project organization }\end{array}$ \\
\hline & & $\begin{array}{l}\text { Plan the project } \\
\text { economy }\end{array}$ \\
\hline & & $\begin{array}{l}\text { Perform procurement } \\
\text { and enter into contracts }\end{array}$ \\
\hline & & $\begin{array}{l}\text { Supervise overall plans } \\
\text { and manage changes }\end{array}$ \\
\hline Perform Ongoing Project & \multicolumn{2}{|c|}{ Manage Corporate Project } \\
\hline Management & & Processes \\
\hline
\end{tabular}

Plan detailed time schedule and resources

Plan the project quality control

Monitor quality, time, resources, and costs

Establish infrastructure for communication

Develop project team cooperation

Promote personnel competences and learning
Characterize corporate project processes

Handle the strategic management processes

Handle project-oriented management functions Handle portfolio management processes

Handle the management of a program

Develop project management professionalism 
Perform Ongoing Project

Management
Manage Corporate Project

Processes

Manage project meetings and

correspondence

Perform personal leadership and

coaching

Support handling of project

execution tasks

\section{PRINCE2}

The structure of PRINCE2 has three elements:

- Processes (management processes)

- Components

- Techniques.

Project management is described as eight processes - from start to completion. Each process describes what to do and when:

- Directing a project

- Starting up a project

- Initiating a project

- Controlling a stage

- Managing product delivery

- Managing stage boundaries

- Closing a project

- Planning.
Eight core components describe the PRINCE2 understanding of project management. The components are in the processes:

- Business case

- Organization

- Plans

- Controls

- Management of risk

- Quality in a project environment

- Configuration management

- Change control.

PRINCE2 offers a number of tools to be selected and adapted to each project 